\title{
Effect of balancing feed additive on growth, development and productivity of cattle
}

\author{
Evgeniya Tuaeva ${ }^{1, *}$, Tamara Krasnoshchekova ${ }^{1}$, Sergei Sogorin ${ }^{1}$, Nikolay Pasechnik ${ }^{1}$, and \\ Yuri Kurkov ${ }^{1}$ \\ ${ }^{1}$ Far Eastern State Agrarian University ,86, Politeknicheskaya Str., Blagoveschensk, Russia
}

\begin{abstract}
The ecological conditions of fodder production and agricultural technology for the cultivation of fodder resources have a great influence on the characteristics in the chemical composition and nutritional value of local fodders, determines their yield and the economic aspect of production. The Amur Region belongs to a biogeochemical region with a sharp deficiency in the biosphere of a number of normalized macro- and microelements vital for animals. In this regard, mineral supplements and premixes for animals and poultry imported from other regions can be not only useless, but even harmful. In order to determine the need for feeding with minerals, you need to know which chemical elements are contained in feed and in the diet in insufficient quantities, and which in excess. Along with this, the normalized microelements introduced into the composition of feed and rations in the form of mineral salts are poorly digested by all types of animals. It is most effective to feed them in combination with organic nutrients. In this regard, the purpose of the experimental research was to study the possibility of using feed additives made from local nontraditional feed resources in feeding cattle. As a result of scientific, economic and physiological (balance) experiments, the effectiveness of using feed additives made from local fodder resources in feeding cattle for growth, metabolism and milk productivity was determined.
\end{abstract}

\section{Introduction}

The current stage in the development of cattle breeding is characterized by ever-increasing requirements for a quantitative increase in production, an improvement in its quality and a reduction in production costs. The solution to this issue in the conditions of the Amur region has its own specific features, which are due to a whole range of natural and climatic conditions that have influenced the nature of the local food base. The Amur region belongs to a biogeochemical region with a deficit in the agrosphere of all normalized microelements $[10,21]$.

The lack of these substances in fodders leads to a decrease in the productivity of animals and the occurrence of endemic diseases. Studies have shown that the fodders of the Amur region do not meet the needs of animals for nutrients, and especially for

\footnotetext{
${ }^{*}$ Corresponding author: tuaeva80@mail.ru
} 
microelements $[8,11]$. In this regard, the problem of providing adequate nutrition for animals, including cattle, should be solved through the production of balancing feed additives $[3,4,7,15]$. Recipes for balancing feed additives must be developed taking into account natural and climatic conditions and modern standardized feeding of animals [5-7].

In the conditions of the Amur region, it is possible to use feed additives made from natural feed resources in animal feeding as a source of biologically active substances. These can be alginates of brown and red algae [9]. In addition, under the conditions of the Amur region, it is possible to use asparaginates of soy protein trace elements in animal feeding [12]. This is due to the fact that soy protein contains $10.2 \%$ aspartic acid.

The study of the effectiveness of the use of local forage resources is devoted to the work of such domestic scientists as N.P. Makartsev (1999), N.N. Maksimyuk (2020), V.I. Fisinin, T.M. Okolelova, I.A. Egorov (2009).

Therefore, consideration of this issue on the efficiency of using local fodder resources in feeding young cattle is relevant.

The purpose of the research was to study the effect of feed additives made from local fodder resources on the growth, metabolism and milk production of first-calf cows.

\section{Materials and methods}

Experimental studies were carried out in the conditions of the dairy complex of Priamurye LLC during 2019. Scientific, economic and physiological experiments were carried out in accordance with the methodological recommendations of the All-Union Agricultural Academy, 1985. Chemical analysis of fodders and excrement was carried out according to generally accepted methods of zootechnical analysis of fodders. The content of minerals was determined using a digital spectrophotometer Unico 1201. The morphobiochemical composition of blood was studied using a StatFax hematological analyzer. Biometric processing of research results was carried out using Microsoft Excel 2013, the significance of differences was determined using the Student's test.

For the study, four groups of heifers, 10 heads in each, were formed according to the analog-pair method (Table 1)

Table 1. Scheme of scientific and economic experience.

\begin{tabular}{|l|c|l|}
\hline \multicolumn{1}{|c|}{ Group } & $\mathrm{n}$ & \multicolumn{1}{c|}{ Feeding conditions } \\
\hline Control & 10 & Basic diet (BD) + standard P62-1 premix (trace elements in mineral form) \\
\hline 1 experienced & 10 & $\begin{array}{l}\text { BD + premix P62-1, containing trace elements in the composition of soy } \\
\text { protein asparaginates }\end{array}$ \\
\hline 2 experienced & 10 & $\begin{array}{l}\text { BD + premix P62-1, containing trace elements in organic form in the } \\
\text { composition of alginates of anfeltia red }\end{array}$ \\
\hline
\end{tabular}

\section{Results}

Experimental studies have shown that with the inclusion in the diet of replacement heifers of normalized microelements in organic form in the composition of soy protein asparaginates and in the composition of red anfeltia, the highest live weight indicators were in both experimental groups in all age periods (Table 2).

For example, when analyzing the results obtained in the first age period, it can be concluded that at the beginning of the experiment, the live weight of heifers was reliably the same. When carrying out control weighing at the age of 6 months, the live weight of heifers from the first and second experimental groups had differences in comparison with the control group and was more by $8.6 \mathrm{~kg}$ and $13.7 \mathrm{~kg}$, respectively. According to the average daily gain, the same tendency for its increase was observed in the experimental 
groups. In the second age period in calves from the control group, the average daily gain was $594 \mathrm{~g}$, in the second experimental group - $624 \mathrm{~g}$, in the third experimental group - 645 $\mathrm{g}$ or as a percentage of the control group in 1 experimental group - by 5.2\%, 2 experimental - by $8.5 \%$. Analyzing the results of the third age period, as well as in the previously studied periods, the heifers from the experimental groups had a higher live weight, higher average daily gains compared to the control group. Besides, when feeding asparaginates of microelements, the indicators for the live weight of heifers at the age of 18 months were higher by $5.1 \%$, and when red anfeltia alginates were included in the diet, by $7.8 \%$.

Table 2. Dynamics of live weight of heifers for the period of their rearing, $M \pm m, n=10$.

\begin{tabular}{|c|c|c|c|c|c|}
\hline Group & $\begin{array}{l}\text { Live weight at } \\
\text { the beginning of } \\
\text { the period, } \mathrm{kg}\end{array}$ & $\begin{array}{l}\text { Live weight in } \\
\text { the end of the } \\
\text { period, } \mathrm{kg}\end{array}$ & $\begin{array}{l}\text { Absolute } \\
\text { gain, } \mathrm{kg}\end{array}$ & $\begin{array}{l}\text { Average } \\
\text { daily } \\
\text { gain, g }\end{array}$ & $\begin{array}{l}\text { In } \% \text { to the } \\
\text { control group }\end{array}$ \\
\hline \multicolumn{6}{|c|}{ I period - age from birth to 6 months } \\
\hline Control & $35.6 \pm 0.70$ & $176.5 \pm 3.22$ & 140.9 & 782 & 100 \\
\hline 1 experienced & $35.1 \pm 0.84$ & $185.1 \pm 3.87$ & 150.0 & 833 & 106.5 \\
\hline 2 experienced & $35.5 \pm 0.89$ & $190.2 \pm 4.44$ & 154.7 & 860 & 109,9 \\
\hline \multicolumn{6}{|c|}{ II period - age from 6 to 12 months } \\
\hline Control & 176,5 & $283.4 \pm 4.74 *$ & 106,9 & 594 & 100 \\
\hline 1 experienced & 185,1 & $297.6 \pm 3.88$ & 112,5 & 625 & 105,2 \\
\hline 2 experienced & 190,2 & $306,3 \pm 7,65$ & 116,1 & 645 & 108,5 \\
\hline \multicolumn{6}{|c|}{ III period - age from 12 to 18 months } \\
\hline Control & 283.4 & $384.7 \pm 7,24$ & 101,3 & 563 & 100 \\
\hline 1 experienced & 297.6 & $404.2 \pm 6.98^{*}$ & 106.5 & 592 & 105,1 \\
\hline 2 experienced & 306.3 & $415.5 \pm 12,40$ & 109.2 & 607 & 107.8 \\
\hline
\end{tabular}
$* \mathrm{P}<0.05$

Optimization of feed rations for normalized microelements, when rearing replacement heifers, had a significant impact on their development in the post-milk period.

The study of linear measurements of replacement heifers in the post-milk period showed that animals from the third experimental group had clear advantages in width and girth of the chest behind the shoulder blades. Heifers that were raised on feed rations using experimental premixes grew in length and height, they developed a stronger skeleton.

At the age of nine months, all studied measurements of heifers were higher in all experimental groups (Fig. 1).

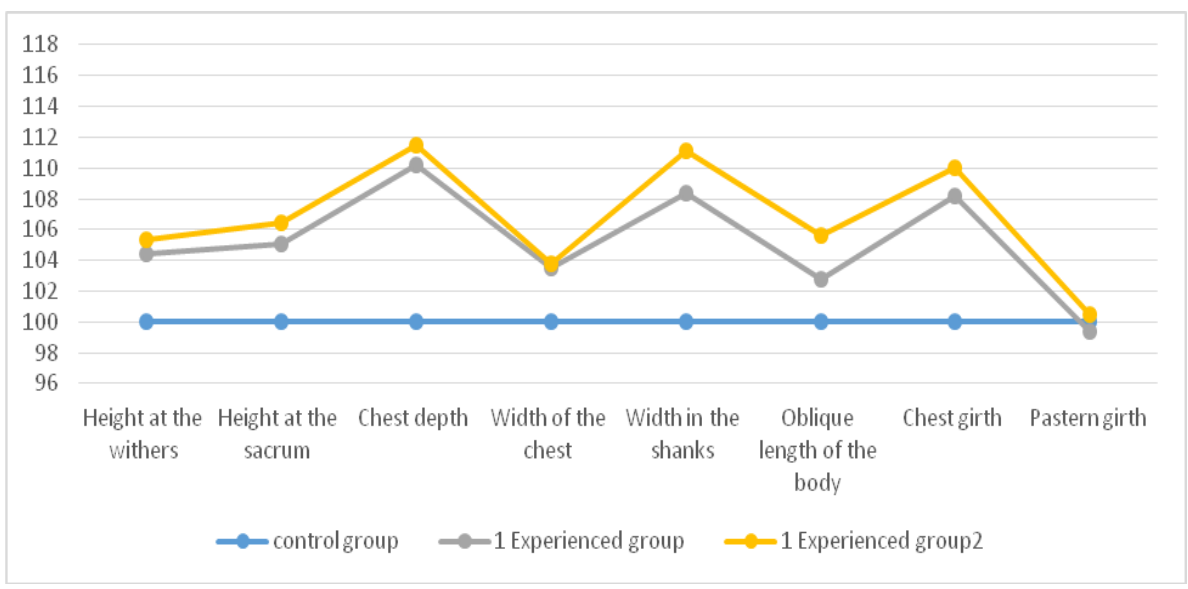

Fig. 1. Exterior profile of heifers at the age of 18 months, $\%$. 
As evidenced by the data obtained on measurements at the age of eighteen months, growth indicators changed unevenly with age, and for all the studied measurements, the heifers of the second experimental group had an advantage. They exceeded the heifers from the control group in height at the withers - by $7.8 \mathrm{~cm}(7.1 \%)$, in height at the sacrum - by $4.8 \mathrm{~cm}(4.4 \%)$, in chest depth - by $3.0 \mathrm{~cm}(6.7 \%)$, along the width of the chest - by $3.0 \mathrm{~cm}$ $(8.8 \%)$, along the width in the shanks - by $3.7 \mathrm{~cm}(9.9 \%)$, along the oblique length of the body - by $7.2 \mathrm{~cm}$ ( $6.1 \%)$, for chest girth behind the shoulder blades - by $4.0 \mathrm{~cm}(2.8 \%)$, for pastern girth - by $1.0 \mathrm{~cm}(6.2 \%)$. (fig. 1).

Based on the above, we can conclude that all animals developed proportionally, according to the standard of the red-and-white breed.

There was no difference between the body build indices in the groups, which indicates the correct selection of analogous animals before testing and their compliance with the plan of growth and development in accordance with the breed (Table 3).

Table 3. Physique indices of replacement heifers at 18 months, $\mathrm{cm}, \mathrm{M} \pm \mathrm{m}$.

\begin{tabular}{|l|c|c|c|}
\hline \multirow{2}{*}{\multicolumn{1}{|c|}{ Index }} & \multicolumn{3}{|c|}{ Group } \\
\cline { 2 - 4 } & control & 1 experienced & 2 experienced \\
\hline Legginess & $50.4 \pm 0.72$ & $48.3 \pm 0.68^{*}$ & $47.4 \pm 1.40$ \\
\hline Elongation & $122.0 \pm 0.73$ & $119.5 \pm 1.22$ & $120.8 \pm 1.40$ \\
\hline Pelvic & $94.4 \pm 0.88$ & $90.6 \pm 1.16$ & $85.8 \pm 1.50$ \\
\hline Chest & $74.0 \pm 0.90$ & $70,0 \pm 1,02^{*}$ & $66.1 \pm 1.49$ \\
\hline Density & $116.7 \pm 1.30$ & $120.6 \pm 1.93$ & $121.5 \pm 2.09$ \\
\hline Boniness & $15.8 \pm 0.35$ & $15.1 \pm 0.58$ & $14.9 \pm 0.68$ \\
\hline${ }^{*} \mathrm{P}<0.05$
\end{tabular}

As a result of processing data on the formation of constitutional features of the physique at 18 months of age, no significant differences were revealed. At the same time, the heifers from the experimental groups were less high-legged, more elongated, and were characterized by higher indices of pelvic, chest and overgrowth.

Determination of the digestibility of feed nutrients in young cattle at the age of 18 months. Physiological experiment was carried out on three heads from each group of animals according to the generally accepted zootechnical method (Table 4).

Table 4. Digestibility of nutrients, $\%, M \pm m, n=3$.

\begin{tabular}{|l|c|c|c|}
\hline \multirow{2}{*}{\multicolumn{1}{|c|}{ Index }} & \multicolumn{3}{c|}{ Group } \\
\cline { 2 - 4 } & control & 1 experienced & 2 experienced \\
\hline Dry matter & $64.8 \pm 0.2$ & $66.7 \pm 0.3$ & $68.8 \pm 0.3$ \\
\hline Organic matter & $67.0 \pm 0.1$ & $69,8 \pm 0.2^{*}$ & $71.6 \pm 0.2^{*}$ \\
\hline Crude protein & $62.1 \pm 0.71$ & $66.4 \pm 0.33$ & $66.8 \pm 0.55$ \\
\hline Crude fat & $57.0 \pm 0.45$ & $58.3 \pm 0.32$ & $59.4 \pm 0,85$ \\
\hline Crude fiber & $53.3 \pm 0.5$ & $57.8 \pm 0.74$ & $57.8 \pm 0.63$ \\
\hline Nitrogen-free extractive substances (NES) & $71.3 \pm 0.51$ & $73.5 \pm 0.63$ & $75.1 \pm 0.70$ \\
\hline${ }^{*} \mathrm{P}<0.05$ & \multicolumn{3}{|l}{} \\
\hline
\end{tabular}

From the data in Table 4, it can be seen that heifers from the first and second experimental groups in terms of digestibility coefficients exceeded heifers from the control group in dry matter by $1.9-4.0 \%$, in organic matter by $2.8-4.8 \%$, in raw protein by $4.3-$ $4.7 \%$, crude fat by $2.3-2.4 \%$, crude fiber by $4.5 \%$ and NES by $2.2-3.8 \%$. This is due to the better process of digestion of the digestive system of animals due to the influence of feed additives that contain normalized microelements in organic form, providing a higher absorption of nutrients and minerals in the intestines and their deposition in the body of animals. 
Analysis of the data obtained indicates that the inclusion of experimental premixes in the diet of red-and-white heifers had a positive effect on the digestibility of nutrients in the diets. The nutrients were the best digested be the heifers from the experimental groups that were fed premixes containing microelements in organic form in the composition of soy protein asparaginates and alginates of anfeltia red.

At the final stage of scientific and economic experience, the morphological and biochemical composition of blood were studied (Table 5).

Table 5. Morphological and biochemical composition of blood, $M \pm m, n=3$.

\begin{tabular}{|l|c|c|c|}
\hline \multirow{2}{*}{\multicolumn{1}{c|}{ Index }} & \multicolumn{3}{c|}{ Group } \\
\cline { 2 - 4 } & control & 1 experienced & 2 experienced \\
\hline Hemoglobin, $\mathrm{g} / \mathrm{1}$ & $91.4 \pm 1.51$ & $114.8 \pm 1.58^{*}$ & $115.1 \pm 1.64$ \\
\hline Leukocytes, $10^{9} / \mathrm{g}$ & $8.4 \pm 0.24$ & $8.9 \pm 0.35$ & $9.0 \pm 0.22$ \\
\hline Erythrocytes, $10^{12} / 1$ & $5.3 \pm 0.12$ & $7.2 \pm 0.17$ & $7.4 \pm 0.25^{*}$ \\
\hline Total protein $(\mathrm{g} / \mathrm{L})$ & $74.2 \pm 1.22$ & $80.1 \pm 1.34$ & $84.3 \pm 1.46$ \\
\hline Iron, $\mu \mathrm{M} / \mathrm{L}$ & $15.3 \pm 0.13$ & $24.3 \pm 0.27$ & $24,9 \pm 0.34$ \\
\hline Copper, $\mu \mathrm{M} / \mathrm{L}$ & $12.5 \pm 0.23$ & $18.3 \pm 0.36$ & $19.0 \pm 0.45$ \\
\hline Zinc, $\mu \mathrm{M} / \mathrm{L}$ & $11.2 \pm 0.22$ & $15.8 \pm 0.54$ & $17.3 \pm 0.69$ \\
\hline Cobalt, $\mu \mathrm{M} / \mathrm{L}$ & $0.30 \pm 0.37$ & $0.43 \pm 0.30$ & $0.56 \pm 0,42$ \\
\hline Manganese, $\mu \mathrm{M} / \mathrm{L}$ & $1.76 \pm 0.57$ & $1.93 \pm 0.82$ & $2.02 \pm 0.90$ \\
\hline Selenium, $\mu \mathrm{M} / \mathrm{L}$ & $0.59 \pm 0.06$ & $0.72 \pm 0.03$ & $0.85 \pm 0.04^{*}$ \\
\hline Chromium, $\mu \mathrm{M} / \mathrm{L}$ & $0.17 \pm 0,06$ & $0.20 \pm 0.07^{* *}$ & $0.28 \pm 0.08^{*}$ \\
\hline Iodine, $\mu \mathrm{M} / \mathrm{L}$ & $0.28 \pm 2.37$ & $0.322 \pm 1.43$ & $0.35 \pm 1.08$ \\
\hline
\end{tabular}

$* \mathrm{P}<0.05,{ }^{* * \mathrm{P}}<0.001$

Morphological and biochemical parameters of blood, except for leukocytes in the blood of heifers, were better compared to control. As for the content of microelements, in heifers from the control group they were within the lower limit of the physiological norm. At the same time, in heifers from the experimental groups, the content of trace elements in the blood reached the physiological norm.

Thus, the results of scientific and economic experience give reason to believe that the inclusion of experimental premixes containing microelements in organic form into the diets of replacement youngsters makes it possible not only to optimize metabolism, stimulate their growth, development, but also improve the micromineral composition of blood.

Milk productivity is the main criterion for evaluating the effectiveness of fodders and feed additives (Table 6).

Table 6. Milk productivity of first-calf heifers in scientific and economic experience, $(\mathrm{M} \pm \mathrm{m})$.

\begin{tabular}{|l|c|c|c|}
\hline \multicolumn{1}{|c|}{ Index } & \multicolumn{3}{c|}{ Group } \\
\cline { 2 - 4 } & control & 1 experienced & 2 experienced \\
\hline Average daily milk yield, kg & $12.1 \pm 0.22$ & $14.6 \pm 0.89$ & $14.8 \pm 0.98$ \\
\hline Fat content in milk, \% & $4.00 \pm 0,14$ & $4.23 \pm 0.40$ & $4.24 \pm 0.48$ \\
\hline Protein content in milk, \% & $3.21 \pm 0.01$ & $3.30 \pm 0.01 *$ & $3.28 \pm 0.01^{*}$ \\
\hline Average daily milk yield with basis fat, $\mathrm{kg}$ & $14.2 \pm 0.52$ & $18.2 \pm 0.87$ & $18.4 \pm 0.99$ \\
\hline$* \mathrm{P}<0.5$ & \multicolumn{3}{|l}{} \\
\hline
\end{tabular}

As a result of studies a positive effect of feeding experimental premixes to first-calf heifers on their milk productivity for 305 days of lactation has been established (Fig. 2). 


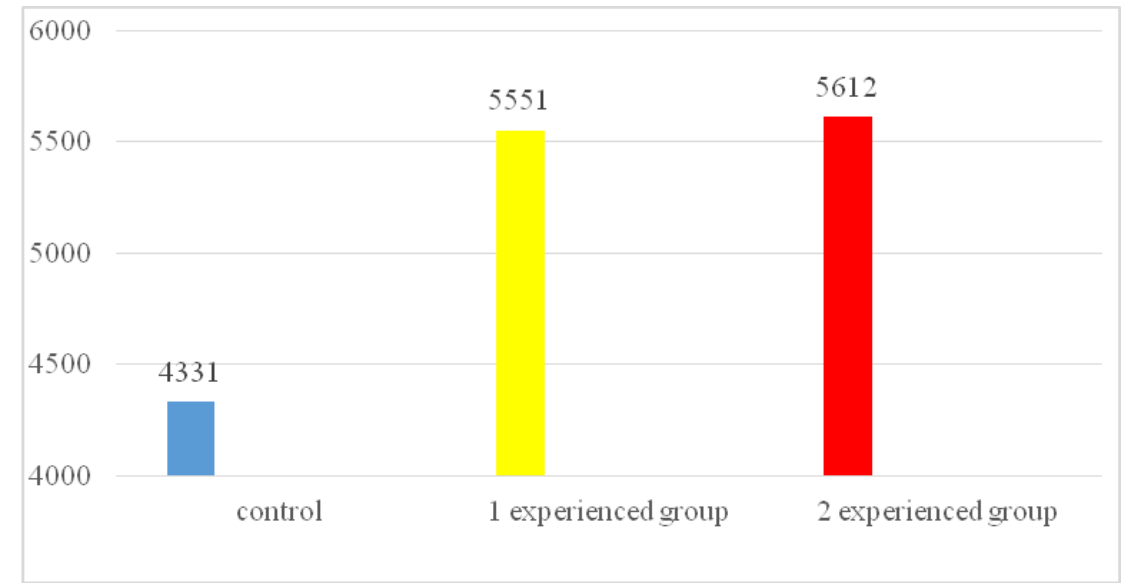

Fig. 2. Milk yield per 305 days of lactation (base fat), $\mathrm{kg}$.

When studying the dynamics of changes in the average daily milk yield, it was found that first-calf heifers from the experimental groups exceeded the control ones in milk yield in the first experimental group - by $4.0 \mathrm{~kg}$, the second - by $4.2 \mathrm{~kg}$. Quality indicators of milk are important indicators of milk productivity. Studies have shown that in the process of lactation of first-calf cows, when feeding them experimental premixes with a diet, the content of fat in milk increased by $0.23-0.24 \%$, and protein - by $0.07-0.09 \%$.

Thus, the use of experimental premixes in the diet contributes to an increase in milk productivity, the content of fat and protein in the milk of red-and-white cows.

After conducting a scientific and economic experiment, an economic justification of its results was carried out on the use of experimental premixes in the diets of replacement heifers in the composition of soy protein asparaginates and alginates of anfeltia red. It was found that the economic effect of feeding them was obtained in the first experimental group - 32.0 rubles, in the second group - 37.5 rubles. per head per day.

Thus, despite the additional costs, the use of experimental premixes in organic form in the composition of soy protein asparaginates and alginates of anfeltia red in the feeding of replacement youngsters contributes to an increase in their growth, development and, in the future, milk productivity. Due to the intensity of metabolic processes, the quality of milk increases and the cost of raising young animals and milk productivity are reduced.

\section{Discussion}

At present, domestic and world practice has scientifically and practically proved that the use of biologically active substances in feeding animals and birds makes it possible to get more products from them while reducing feed costs $[1,13]$. Traditionally used in the composition of feed rations, normalized trace elements in the form of mineral salts are not optimal for ensuring the vital activity of animals due to their low bioavailability [19].

Chelated (organic) forms of microelements in combination with amino acids are highly bioavailable $[14,17]$.

In the conditions of the Amur region, feed additives made from local fodder resources rich in biologically active substances, including normalized microelements in organic form, can be used.

The results of the studies presented in this article on the use of non-traditional forage resources in animal feeding have been confirmed by the works of scientists from other regions of Russia [2,16,18,20]. 
The use of normalized microelements in organic form as part of non-traditional foder resources in diets for cattle contributes to a significant increase in growth, the development of replacement young animals, the intensity of metabolic processes and, in the future, milk productivity.

\section{Conclusion}

Based on the research presented in the scientific article, it is possible to draw deductions.

1. In a comparative study of premixes in mineral and organic forms, it was found that when feeding the heifers with a premix in which all the normalized trace elements were in organic form, it contributed to an increase in the average daily gain, digestibility and absorption of nutrients. The hematological indices for the assimilation of microelements in the experimental groups reached the physiological norm.

2. In the process of lactation of first-calf cows, the average daily milk yield was higher than in the control in both experimental groups, when feeding them asparaginates of microelements by $20.7 \%$, of alginates of red anfeltia - by $22.3 \%$.

3. With the economic substantiation of the research results, the effectiveness of feeding soy protein asparaginates and alginates of anfeltia red, containing normalized microelements in organic form, has been established. The economic effect per head per day was 32.0 rubles in the first experimental group, 37.5 rubles - in the second one.

\section{References}

1. A.B. Arkhipov The need to control the nutritional value of feeding the highly productive cows Chief zootechnician, 4, 35-43 (2006)

2. Kh. A. Amerkhanov, F.G. Kayumov The state of livestock breeding in Russia , Zootechnics, 1, 24 (2008)

3. O. Yu. Bryukhno, S. V. Chekhranova, K. S. Tanyushina, V. G. Dikusarov Efficiency of using premixes in feeding calves Bulletin of the Nizhnevolzhsky agro-university complex, 33, 1, 163-169 2014

4. L.N. Gamko, A.N. Gulakov, E.V. Novikova, A.A. Ryazhnov Influence of natural mineral additives on the productivity of young cattle Tauric Scientific Observer, 5-2 (10), 106-110 (2016)

5. L.N. Gamko, N.A. Semuseva Influence of a complex fodder additive on productivity and some morphobiochemical blood parameters Agrarian science, 3, 18-19. (2017)

6. Sh. S. Gafarov Efficiency of feed additives in feeding ruminants, Agrarian education and science, 3, P.3. (2014)

I. F. Gorlov, V. A. Baranikov, N. A. Yudina, N. N. Esaulenko, V. V. Erokhin Influence of feeding multifunctional feed additives on the growth rate of heifers, Dairy and beef cattle breeding, 2,.24-26. (2015)

7. E. S. Dubkova, T. A. Krasnoshchekova, E. V. Tuaeva, V. V. Uvarov, V. V. Shishkin Influence of mineral and vitamin feed supplement feeding on milk productivity of first heifers, Zootechnics, 1, 10-11. (2011)

8. N. Sh. Kaisheva, N.M. Arkhipova, A. Sh. Kaishev Morphological, anatomical and phytochemical characteristics of some algae Pharmacy and Pharmacology, 3, 28-40. (2014)

9. T. A. Krasnoshchekova, A. S. Prostokishin, V. A. Ryzhkov, K. R. Babukhadiya, E. V. Tuaeva, V. Ts. Nimaeva Use of non-traditional feed additives to replenish the lack of chromium in animals and poultry, Zootechnics, 3, 20-21.(2014) 
10. T.A. Krasnoshchekova, E.V. Tuaeva, K.R. Babukhadia, V.Ts. Nimaeva Optimization of feeding of cattle and poultry in the Amur region (monograph) 116 (2012)

11. T.A. Krasnoshchekova, V.A. Ryzhkov, E.V. Tuaeva, Yu.B. Kurkov, V.Ts. Nimaeva Optimization of micromineral nutrition of young cattle and pigs by using nontraditional fodders and chelated compounds of normalized microelements, Achievements of science and technology of the agro-industrial complex, 12, 37-40 (2013)

12. N. G. Makartsev. Feeding farm animals 639 (2012)

13. V.N. Nikulin, I.A. Babicheva, R.Z. Mustafin Regularities of changes in hematological parameters of young cattle under the influence of feed additives and microbial preparations, News of the Orenburg State Agrarian University, 5 (55),146-148 (2015)

14. V.A. Ryzhov, E.S. Ryzhova, V.P. Korotkiy, A.L. Esipovich, O.A. Kazantsev, A.S. Zenkin Coniferous-energy feed additive for livestock breeding Scientific and methodological electronic journal Contept, 26, 346-350 (2014)

15. I.V. Toporova Modified forms of microelements for feeding animals and poultry, Poultry farm, 11, 14-15 (2006)

16. V. Fisinin, P. Suray Natural minerals in the feeding of animals and poultry Livestock breeding of Russia, 8, 66-68 (2008)

17. Frolov, O. Filippov, S. Furmanov, V. Lee Bioplexes of trace elements in premixes for calves Dairy and meat cattle breeding, 3. P.18-20 (2010)

18. F.S. Khaziakhmetov Rational feeding of animals: textbook, 368 (2011)

19. M. Chabaev, R. Nekrasov, V. Nadeev Organic microelements for industrial pig breeding Compound feeding stuffs, 6, 77-79 (2013)

20. R.L.Sharvadze, T.A. Krasnoshchekova, S.N.Kochegarov, L.I. Perepelkina, Yu. B. Kurkov, V.V.Samuylo Influence of feeding a complex mineral and vitamin supplement on milk productivity and milk quality in first-calf heifers, Zootechnics, 5, 8-9 (2012) 